He was the second director of the Computing Section of the British Astronomical Association, formed in the 1920-21 session, a position which he held with only one or two minor interruptions until 1938. The annual production of the "Handbook" required much time and patience, especially with computers who had to be initiated into the subtleties of the calculations essential for the work. Levin displayed a wonderful amount of tact and judgment in teaching now computers, and his unfailing courtesy and kindness will never be forgotten by those who could always turn to him for advice and guidance.

The "Handbook" is used at many of the great observatories for the information that it supplies on various branches, not least that dealing with the ephemerides of comets, for which the perturbations by the major planets have been computed. In this connexion reference may be made to the last great computational work that Levin undertook, in collaboration with Mr. J. G. Porter, his successor as director of the Computing Section. This was the computation of the perturbations of the planets on Comet Pons-Winnecke for two revolutions, Cowell's method being used for the greater portion of the work. The comot was found almost exactly in its predicted position by van Biesbroeck, an indication of the accuracy of the calculations. Levin made a speciality of tho mutual eclipses and occultations of Jupiter's satellites, and a full description of his method of prediction appeared in the Memoirs of the British Astronomical Association, 30, 3, December 1934. Ho was elected president of the Association for the sessions 1930-32 and proved himself a very popular and efficient officer.

It is characteristic of Levin's love for astronomy that he presented his 4-inch refractor to the Association this year, and he has also left all his astronomical books and his 6-inch telescope and observatory, now at Selsoy, to the Association. He leaves a widow and one son, the latter serving in the Navy.

\section{Dr. G. D. Lander}

George Druce Lander, who died on October 25, aged sixty-five, was a man with a strong personality and a chemist whose work was characterized by breadth of outlook and soundness of judgment.

Lander studied chemistry at the Royal Colloge of Science and Birkbeck Institution, London. After working with Japp in Aberdeen on the synthesis of pentacarbon rings, he proceeded to St. Andrews, where ho assisted Purdio in his researches in stereochemistry. Purdio and Lander observed that the product obtained by the action of ethyl iodide on the silver salt of optically active lactic acid possessed a higher rotation than ethyl lactate prepared by the usual esterification process, and they suspected that the higher value was due to the presence of a small amount of the ethoxy derivative. This and similar observations led Purdie and his associates to devise the silver oxide - alkyl iodide method of alkylation, a reaction which afterwards proved to be the most serviceablo tool in the hands of organic chemists of the St. Androws and Birmingham Schools for the controlled degradation of carbohydrates. At University College, Nottingham, Lander made a study of the chemistry of imino-ethers, and in 1903 he was appointed to the chair of chemistry and toxicology at the Royal Veterinary College, London.

In order to deal satisfactorily with the increasing number of cases of suspected poisoning among animals on which ho was consulted, Lander found it necessary to make a comprehensive experimental survey of the methods for the detection of mineral and other poisons. Some results of this work were published in communications to the Analyst. Cir. cumstances also arose which led him to investigate the separation and identification of very minute amounts of alkaloidal drugs, and a short paper entitled "Microanalysis of Alkaloids" was after. wards published in tho Analyst. His skill in manipulas. tion contributed to his success in this field, in which he was actively interested for the remainder of his life.

Lander retired from the Royal Veterinary College in 1920. The well-known "Systematic Inorganic Chemistry" by Caven and Lander was published in 1906, and Lander's "Veterinary Toxicology" in 1913. Lander was a member of the Court of Governors of Birkbeck College for some years, and an examiner in chemistry and toxicology for the Royal College of Veterinary Surgeons from 1923 until 1939. After his retirement from teaching ho resided at Tenterden, Kent, and dovoted much time to the municipal affairs of that ancient borough. Ho leaves a widow, who gavo him much assistance in his analytical work.

G. IV. Crougr.

WE regret to announce the following deaths :

Dr. William H. Brown, lecturer in botany in the Johns Hopkins University, formerly director of the Bureau of Science at Manila, on November 9, aged fifty-five years.

Dr. Livingston Farrand, emeritus president of Cornell University, formerly professor of anthropology in Columbia University, on November 8 , aged seventy-two years.

Prof. E. A. Gardner, emeritus professor of classical arch $x$ ology in the University of London, on November 27 , aged soventy-seven years.

Prof. Waldemar Lindgren, formerly professor of geology in tho Massachusetts Institute of Technology, on November 3, aged seventy-nine years.

Prof. F. K. Richtmyer, professor of physics in Cornell University, on November 7, aged fifty-eight years.

Mr. A. A. Simpson, C.M.G., C.B.E., president of the Royal Geographical Society of Australasia, well known for his explorations in Australia, on November 27 , aged sixty-four years.

Prof. Charles Vaillant, formerly director of the $\mathrm{X}$-Ray Departments in the Baudeloque Clinic and the Lariboisière Hospital, one of the most eminent X-ray pioneers, on 'December 4 , aged seventy-seven years. 